\author{
Natalia Józefacka-Szram
}

Uniwersytet Śląski

Dawid Marszałek

Akademia Pedagogiki Specjalnej

\title{
Szachy w edukacji szkolnej - sposób na poprawę kompetencji i umiejętności przydatnych w szkole i w życiu
}

Szachy to jedna z najpopularniejszych gier na świecie. Gracze spędzają często tysiące godzin na treningach, przygotowujących ich do zawodów. Dla psychologów poznawczych szachy są tym czym muszka owocówka dla genetyków. Naukowcy dowiedli, że wysoki poziom inteligencji nie jest niezbędny do osiągnięcia mistrzostwa w grze w szachy. To czyni tę grę dostępną dla wszystkich i wierzy się, że jest ona rekomendowana szczególnie dla dzieci z ryzykiem SPE. Okazuje się bowiem, że wiedza zdobyta podczas nauki gry w szachy może być wykorzystywana zarówno w szkole jak i w codziennych aktywnościach. Artykuł składa się z trzech części. Pierwsza opisuje szachy z kulturowej, politycznej i naukowej perspektywy. Następnie omówiono proces prowadzący do udziału w zawodach, a także do różnych społecznych i poznawczych zdolności, które można nabyć grając w szachy. Ostatnia część opisuje transfer wiedzy i umiejętności dotyczących szachów, który ma miejsce wśród dzieci ze SPE.

Słowa kluczowe: szachy, rozwój poznawczy, dzieci z grup ryzyka

\section{Chess playing in education as a way of improving social skills needed in school and everyday life}

Chess are one of the most popular games in the world. Chess players often spend thousands of hours to practice for the championship. In turn, for scientists, especially for cognitive psychologists, chess is as the fruit fly (Drosophila melanogaster) is for genetics. Scientists have proved that a high IQ is not necessary to achieve mastery or even a high performance in chess. This makes the game accessible for everyone and we believe that it should be recommended particularly for children with a risk of school failure. It turns out, that knowledge acquired while learning and chess playing could improve skills useful both in school or in everyday life. The article consists of three parts. The first one describes chess from cultural, political, and scientific research perspective. Then we will discuss the process that leads to taking part in a championship and the various social and cognitive abilities that can be acquired when playing chess. The last part describes the transfer of knowledge and skills concerning chess that occurs among school children with special educational needs.

Keywords: chess, cognitive development, children with a risk school failure 
„Wziąwszy je tedy na spokojne gmachy,

Ukazat palcem na toczone szachy

I rzekt: W tych szrankach wasza bitwa będzie,

Duższy na tonie u mej córy siędzie".

Szachy, Jan Kochanowski

Poemat Kochanowskiego, którego powstanie datowane jest pomiędzy 1562 a 1566 rokiem, opisuje rywalizację pomiędzy Fiedurem i Borzujem, którzy, starając się o wdzięki córki króla duńskiego Tarsesa, postanowili stoczyć pomiędzy sobą rycerski pojedynek. Władca, chcąc uniknąć rozlewu krwi, postanowil, że o rozstrzygnięciu sporu stanowić będzie rezultat partii szachowej. Poemat ten poza walorami artystycznymi wskazuje na wielowiekową tradycję szachową w Polsce, a ponadto podkreśla ceniony od co najmniej czasów odrodzenia prymat intelektu nad tężyzną fizyczną, która to pełnić winna służalczą rolę. Jak przekonuje bowiem Polski Związek Szermierczy fechtunek "(...) jest synergią przewidującego umysłu i posłusznego mu ciała". Czy zatem szachy mogą rozwijać i wspomagać sprawność umysłu? Celem niniejszego artykułu jest przybliżenie informacji mogących pomóc odpowiedzieć na tak zadane pytanie przede wszystkim w odniesieniu do dzieci z trudnościami szkolnymi. Właściwszym zatem pytaniem byłoby: czy trening szachowy może wspomóc proces wyrównywania szans uczniów zagrożonych niepowodzeniem szkolnym (zwanych dalej uczniami o specjalnych potrzebach edukacyjnych SPE)? Rozważania te poprzedzone są opisem samej gry, jak i mistrzów szachowych, a dokładniej cech, które sprawiają, że szachy stały się tym dla psychologii poznawczej, czym muszka owocowa dla genetyki [Simon, Chase 1973]. Akcent całego artykułu skierowany znów będzie na inteligencję, która to najczęściej absorbowała uwagę badaczy, a zarazem dzieci z obniżonym jej poziomem szczególnie, które potrzebują stosownie dobranego wsparcia.

\section{Wielka szachownica. Cele polityki edukacyjnej Polski i Parlamentu Europejskiego}

Szachy są popularną grą, będącą elementem kultury nie tylko europejskiej. Stanowi ona również samodzielną dyscyplinę sportową, w której rozgrywane są liczne turnieje o zasięgu międzynarodowym, a mistrzowie szachowi osiągający w nich sukcesy odnoszą również powodzenie w biznesie, nauce, polityce. Szachy stają się produktem oferowanym konsumentom oraz przedmiotem zainteresowania badaczy [Charness 1992]. Gra ta była tematem obrad Parlamentu Europejskiego [PE 2012], który, argumentując m.in, że „(...) bez względu na wiek dziecka szachy mogą poprawić jego koncentrację, zwiększyć cierpliwość i wytrwałość, 
a także rozwinąć zmysł twórczy, intuicję, pamięć oraz umiejętności analitycznego myślenia i podejmowania decyzji", zalecił krajom członkowskim wprowadzenie programu „Szachy w szkole”. W Polsce instytucją, która postanowiła zrealizować zalecenia Parlamentu Europejskiego, jest Polski Związek Szachowy (PZSzach), który we wspólpracy m.in z władzami samorządowymi, wojewódzkimi kuratoriami oświaty oraz partnerami ze sfery pozabudżetowej od 2013 r. poprzez trenerów i przeszkolonych nauczycieli, oferuje w szkołach i przedszkolach zajęcia szachowe. Obecnie inicjatywa ta zwana "Edukacją przez Szachy w Szkole” ma ogólnopolski charakter [PZSzach, 2014], a sam pomysł PE najwyraźniej zyskał uznanie Minister Edukacji Narodowej (MEN) Anny Zalewskiej, która w wywiadzie udzielonym dla TVP Info zapowiedziała wdrożenie reform mających na celu utworzenie "(...) nowoczesnej, dwudziestopierwszowiecznej szkoły odpowiadającej na wyzwania cywilizacyjne, a jednocześnie pamiętającej o tym, że trzeba łączyć to co nowoczesne z tradycyjnym". Minister podkreśliła zarazem, że "(...) $\mathrm{w}$ pierwszej klasie pojawią się podstawy programowania czy podstawy gry w szachy, dlatego, że chcemy tak uczyć matematyki, z którą mamy duży problem" [TVP Info 2016, w Polityce 2016].

Zadać jednak należy pytanie czy przekonanie osób mających wpływ na uregulowania prawne $\mathrm{w}$ systemie oświaty o pozytywnym wpływie treningu szachowego znajdują wystarczające potwierdzenie w badaniach naukowych; zwłaszcza w odniesieniu do uczniów ze SPE? Innymi słowy: co dotychczas wiadomo na temat transferu wiedzy i kompetencji zdobywanych $w$ ramach treningu szachowego na osiągnięcia szkolne.

\section{Szachy jako przedmiot badań}

Szachy od kilkudziesięciu lat są użyteczne jako narzędzie w laboratoryjnych badaniach psychologicznych, ponieważ stwarzają one idealny kompromis pomiędzy możliwością kontroli warunków badania (proste zasady gry) a trafnością zewnętrzną, ekologiczną (możliwość stwarzania $2^{143}$ różnych sytuacji), posiadają rankingi pozwalające na obiektywne porównywanie biegłości szachowej w odniesieniu do notowanych graczy i/lub grup (pierwowzorem rankingów, nie tylko szachowych, jest opracowana przez Arpada Elo w latach 50. XX wieku metoda, w której oczekiwaną pozycję gracza traktuje się jako zmienną losową o rozkładzie normalnym o średniej wynoszącej $M=1500^{1}$ oraz odchyleniu standardowym

Dzieci o rankingu ELO wynoszącym 1100 (tj. 2 odchylenia standardowe poniżej średniej) bez trudu pokonać mogą dorosłych okazjonalnie grających w szachy, tytuł mistrzowski rozpoczyna się od ELO wynoszącego 2100 (tj. 3 odchylenia powyżej średniej), a tytuł arcymistrza szachowego uzyskują osoby z rankingiem powyżej 2500 (tj. 5 odchyleń standardowych powyżej średniej. 
równym $S D=200$ [Glickman 1995; Glickman, Jones 1999]. Rankingi ELO (zwane tak na cześć autora) umożliwiają porównywanie postępów w odniesieniu do innych szachistów, dzięki czemu są cenną bazą osób umożliwiającą dostęp do graczy o żądanej przez badacza biegłości szachowej. Partie szachowe rozgrywane mogą być $\mathrm{z}$ innym graczami twarzą $\mathrm{w}$ twarz, za pośrednictwem komputera lub też $\mathrm{z}$ wirtualnym przeciwnikiem wykreowanym $\mathrm{w}$ stworzonych aplikacjach. Łatwy dostęp do milionów partii (utworzonych m.in. z protokołów rozgrywek turniejowych) często stanowią interesujący materiał testowy, który jest wykorzystywany podczas badań [Campitelli, Parker, Head, Gobet 2008], a ponadto cechy leżące $u$ podstaw eksperckiej wiedzy nie są ściśle związane $\mathrm{z}$ wiekiem biologicznym, co powoduje, że zmienna wieku przestaje być zmienną zakłócającą (Confounder) [Schneider, Gruber, Gold, Opwis 1993].

\section{Możliwości uzyskania poziomu eksperckiego}

Gobet i Charness [2006] na podstawie przeglądu badań scharakteryzowali cechy, jakimi odznaczają się eksperci szachowi, tj. większą częstotliwością ruchów sakkadowych oka, większą odległością punktów fiksacji, które zarazem obejmują swym zasięgiem większy obszar widzenia, skierowane są na znaczące pola i figury szachowe (zwłaszcza w pierwszych sekundach ekspozycji), a zarazem zogniskowane są na peryferiach obserwowanego obiektu. Osoby te posiadają znaczącą większą ilość zapamiętanych modułów (chunk, jednostka percepcji w szachach, na którą składa się kilka pionów i nadane im semantyczne znacznie) zgrupowanych $w$ ramach większych schematów ułożenia pionów (templates) magazynowanych w pamięci długotrwałej. Przy podejmowaniu decyzji koncentrują się na strategicznych pozycjach pionów, dokonują intensywnego przeszukiwania zasobów pamięciowych (depth of search) i częściej wybierają stereotypowe rozwiązania, zaś dotychczas nieznanym rozmieszczeniom figur potrafią szybko nadać sensowne znaczenie. Sumarycznie cechy te sprawiają, że podejmują oni trafniejsze decyzje, również w obliczu presji czasu, przy czym umiejętności te ograniczone są jedynie do dziedziny, w której uzyskali oni ekspercki poziom tj. szachów [Ericsson, Charness 1994; Schneider, Gold, Opwis 1993].

Ustalenia wsparte symulacjami przeprowadzonymi $\mathrm{w}$ konstruowanych programach komputerowych naśladujących graczy szachowych pozwoliły na wyjaśnienie procesu percepcji u szachistów [Simon, Chase 1973]. W ramach opracowanej przez autorów teorii, podstawowa jednostka percepcyjna - chunk-skonstruowana jest z około 7 pionów, których ułożenie na szachownicy umożliwia nadanie im semantycznie wspólnego znaczenia. Posługując się analogią do ilości 
słów niezbędnej do sprawnego używania języka w komunikacji, wysunęli przypuszczenie, że do osiągnięcia poziomu eksperckiego w szachach konieczne jest w przybliżeniu utrwalenie w pamięci ok. 50. tys. różnych konfiguracji ułożeń pionów, co przekłada się na m.in. 10. tys. godzin treningu, czyli około 10 lat. Hipoteza ta została rozszerzona przez Ericssona, Krampe'a i Tesch-Römera [1993], którzy na podstawie przeglądu literatury oraz badań własnych (przeprowadzonych na skrzypkach i pianistach) przekonują, że hipotezę tą rozszerzyć można nie tylko do dyscyplin sportowych czy muzycznych, ale dotyczyć może ona każdej dziedziny życia. Powyżsi autorzy zaproponowali trajektorię rozwojową biegłości eksperckiej. Zakłada ona, że część $\mathrm{z}$ dzieci przewyższa swoich rówieśników w danej aktywności, przez co częściej się w nią angażują.

Dostrzegając sprawność swych podopiecznych, rodzice podejmują działania, które mogą przyśpieszyć wzrost tychże biegłości, a gdy dzieci osiągają wystarczający wiek, samodzielnie decydują o zintensyfikowaniu ćwiczeń. Kluczowy dla tego podejścia jest metodyczny trening (deliberate practice), który prowadzony może być przez instruktora i ukierunkowany jest na podnoszenie sprawności ściśle skonkretyzowanych i prostych zadań (adekwatnie trudnych do wieku i możliwości uczniów), dzięki czemu dostarcza on (zarówno instruktor, jak i trening sam w sobie) wielu informacji zwrotnych o poziomie ich wykonania, a wielokrotność powtórzeń sprzyja redukcji błędów. W tej koncepcji pomiędzy mistrzostwem a treningiem zachodzi związek funkcyjny, w którym poziom ekspercki ściśle uzależniony jest od kumulatywnej ilości godzin treningu, lecz długotrwałe ćwiczenia nie tyle ilościowo zwiększają skuteczność wykonywania działań, co przemodelowują poznawcze schematy działania (changes in cognitive mechanisms), dzięki czemu procesy zaangażowane $\mathrm{w}$ wykonywanie działań uzyskują nową, odmienną jakość [Gobet, Charness 2006]. Dodać należy, że dzieci wcześniej rozpoczynające trening szybko uzyskują znaczącą przewagę, np. prawdopodobieństwo uzyskania tytułu mistrzowskiego wśród graczy, których przygoda z szachami zaczęła się przed 12. r.ż. wynosi 0,24 podczas gdy dla ich rywali debiutujących po 12 r.ż. wynosi ono zaledwie 0,02 . Wydaje się zatem słuszne przypuszczenie Gobeta o okresie sensytywnym, który według autora przypada na okolicę piątego roku życia [2013].

Związek pomiędzy długotrwałym treningiem a poziomem wykonania wykazany został dla wielu dziedzin nie tylko w muzyce czy sporcie, ale również w skutecznym uczeniu się, pisaniu, liczeniu [zob. Ericsson, Charness, Feltovich, Hoffman 2006]. Nie sposób jednak nie zgodzić się z szeregiem uwag krytycznych wysuwanych przez Sternberga [1996], który między innymi sygnalizuje możliwość objawiania się talentu właśnie przez intensywne angażowanie się w treningi, a wtórują mu badacze, których wyniki badań jedynie częściowo potwierdzają pozytywny wpływ metodycznego trenowania na osiągniecia szachowe. Gobet 
i Campitelli [2007] podkreślają np., że do osiągniecia poziomu mistrzowskiego uczestnicy badań potrzebowali średnio 11503 godzin treningu $(S D=5538)$, jednak rozpiętość czasu wynosiła od 3016 do 23608 godzin [zob. też Howard 2009, 2012]. Z kolei Campitelli i Gobet [2008] sygnalizują, że mistrzowie odznaczali się w przeszłości m.in szybszym przyrostem zdolności szachowej w porównaniu, do mniej biegłych graczy. Ponadto metodyczny trening wyjaśnia w szachach $34 \%$ wariancji zmiennej biegłość, w muzyce $21 \%$, w sporcie $18 \%$, a w edukacji $4 \%$ [Hambrick i in. 2014; Macnamara, Hambrick, Oswald 2014].

Nie bez znaczenia jest również fakt sygnalizowany przez Bilalić, McLeod, Gobet [2007], dotyczący kwestii, że dotychczas nie poświecono wystarczającej uwagi osobom, które nie wytrwały tak długotrwałego treningu i przyczyn, dlaczego postanowiły go przerwać (drop-out). Pewne informacje dostarczył jednak zespół prowadzony przez de Bruin i Smits [2008], który dokonał pomiaru utalentowanej szachowo młodzieży. Corocznie Duńska Federacja Szachowa (DFC) rekrutuje spośród młodzieży 10 graczy z najwyższym krajowym rankingiem ELO, których zaprasza do uczestnictwa w narodowym szkoleniu szachowym. W badaniu uczestniczyło 48. uczestników narodowego treningu oraz 33. osoby, które porzuciły dalsze szkolenie (średni wiek wynosił 16,19; $S D=2,75)$. Autorzy Ci, wykorzystując analizę hierarchicznych modeli liniowych, wykazali słuszność założenia Ericsson i współpracowników [1993, s. 387] o monotonicznym wpływie metodycznego treningu na poziom biegłości, tj. zarówno ranking szachowy osób, którzy poprzestali, jak i tych, którzy w dalszym ciągu uczestniczą w projekcie, zależny był ścisłe od kumulatywnej liczby godzin treningu. Innymi słowy, osoby, które przestały uczestniczyć $\mathrm{w}$ zajęciach prowadzonych przez DFC, sumarycznie przeznaczały mniej czasu na treningi, jednakże obie grupy uzyskały zbliżone rezultaty z każdej przeznaczonej godziny na naukę. Zarazem wyniki wcześniejszych pomiarów przeprowadzonych na tej samej próbie sugerować mogą, że u podłoża mniejszego zaangażowania w rozwój biegłości szachowej leżeć może odmienna motywacja, tzn.: obie grupy w równym stopniu ukierunkowane są na wzmacnianie biegłości szachowej, jednakże osoby wytrwale kontynuujące szkolenie w narodowym programie znacząco bardziej pragną zostać mistrzami szachowymi [de Bruin, Rikers i in. 2007]. Podobnego zdania co do roli motywacji w osiąganiu mistrzostwa jest $68,87 \%$ spośród 597 graczy (ELO = 2160,99; $S D=166,58)$. W niej właśnie najczęściej upatrywali oni przejawów naturalnego talentu, który konieczny jest ich zdaniem $(83,57 \% ; n=633)$ do uzyskania najwyższych 10 pozycji w rankingu FIDE. W zgodzie z powyższym jest również przekonanie około połowy z nich, że zdobycie tytułu arcymistrza szachowego wyłącznie dzięki intensywnym treningom jest niemożliwe, a zarazem nieosiągalne dla większości graczy [Howard 2012]. 


\section{Poziom ekspercki - czy jest konieczny do transferu wiedzy}

Chcąc udzielić odpowiedzi na pytanie czy treningi szachowe dla dzieci i młodzieży mogą wspomagać ich nauczanie w szkole, a także ustalić czy możliwe jest osiągniecie pozytywnego wpływu w czasie krótszym niż 10 lat (bowiem okazać się może, że pierwsze efekty zauważalne mogą być dopiero po opuszczeniu murów szkolnych przez podopiecznych). Badania pokazują [zob. Nicotera, Stuit 2014], że w początkowym okresie nauki gry, zdolności, które są konieczne do nabywania biegłości i wiedzy szachowej, są spójne również ze zdolnościami potrzebnymi $w$ innych dziedzinach życia (umiejętności matematyczne, kompetencje społeczne, pamięć). Dlatego też właściwsze jest pytanie o niezbędną długość treningu, który jest potrzebny nie tyle do zdobycia mistrzostwa (które nie gwarantuje transferu wiedzy), ale do odkrycia najefektywniejszego czasu, podczas którego poza rozrywką i nauką towarzyszącą grze w szachy, towarzyszyć będzie poprawa kompetencji i umiejętności przydatnych w szkole i w życiu. Z raportów włączonych do metaanalizy przeprowadzonej przez cytowanych autorów wywnioskować można, że pozytywne efekty możliwe są do zaobserwowania po około 30 lekcjach odbywających się w ciągu całego roku szkolnego, choć wyniki prowadzonych systematycznie badań we Włoszech dostarczają przekonujących danych, że w przypadku szkoleń kierowanych przez certyfikowanego instruktora rezultaty widoczne są już po około 14 godzinach [Trinchero 2013], nawet jeśli okres trwania treningu wynosi jedynie 2,5 miesiąca [Sala, Gorini, Pravettoni 2015].

Ustalenia ograniczające role metodycznego treningu nie tyle podważyły jego rolę, a raczej uzasadniają słuszność tezy zawartej w tytule artykułu, w którym autorzy przekonują, że długotrwałe szkolenie jest konieczne, lecz niewystarczające (necessary but not sufficient) [Campitelli, Gobet 2011]. Danych wspierających ten punkt widzenia dostarczają publikacje badaczy poszukujących innych czynników mogących wpływać na nabywanie mistrzowskich kompetencji [zob. Hambrick, Macnamara, Campitelli, Ullén, Mosing 2016], a spośród nich największą uwagę poświęcono inteligencji.

\section{Sukces $\mathrm{w}$ treningu szachowym - czy zależy tylko od inteligencji?}

Frydman i Lynn [1992] w badaniach przeprowadzonych w Belgii wykazali, że dzieci $(n=11)$, których ranking ELO był większy niż 1550, charakteryzowały się wyższą inteligencją na skali niewerbalnej WAIS $(131, p<0,01)$ niż ich mniej biegli szachowo rówieśnicy (124; $\mathrm{n}=11)$, których ranking wynosił od 1000 do 1350. Obie grupy połączono z trzecią (ELO <1350-1550>) i ustalono, że średnio uczestnicy 
badania (n=33) uzyskali ilorazy równe 121, 109 i 129 odpowiednio w skali pełnej, werbalnej i niewerbalnej.

Związek inteligencji z biegłością szachową $(r=0,619 ; p<0,05)$ dostrzegli również Horgan i Morgan [1990], którzy spośród 113 dzieci z klas 1-12 wybrali 15 najlepszych graczy i dokonali pomiaru Testem matryc Ravena (TMR) oraz wykorzystali ćwiczenie zwane dylematem czy też problemem skoczka szachowego

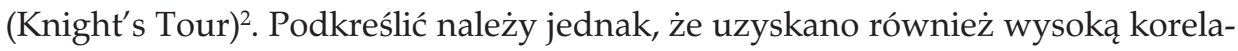
cję $(r=0,727 ; p<0,05)$ pomiędzy wynikiem TMR a klasą, do której uczęszczały dzieci, jednakże przeprowadzona analiza regresji częściowej (z wyłączeniem wieku dzieci) ponownie wskazała na umiarkowany związek inteligencji i szachów $(r=0,518 ; p<0,05)$.

Trudne w interpretacji wyniki uzyskali Bilalić i współpracownicy [2007], którzy dokonali pomiaru m.in inteligencji (wykorzystując wyniki czterech skal testu WAIS ${ }^{3}$ ) przeliczonych na wynik ogólny, a następnie zastosowali hierarchiczne modele liniowe ( $w$ ramach analizy, model pierwszy skonstruowany został przez zmienną [I] płeći i wzbogacany był kolejno przez [II] wiek, [III] IQ, [IV] długość treningu, [V] doświadczenie turniejowe). Wyniki wykazały, że w grupie 57 dzieci, będących od co najmniej czterech lat aktywnymi członkami kółek szachowych, zaobserwować można pozytywny związek pomiędzy IQ a poziomem biegłości szachowej, podczas gdy analogiczna analiza przeprowadzona dla 23 elitarnych graczy wyłonionych z wyżej opisanej grupy (tj. uczniów notowanych w brytyjskim rankingu szachowym; po przeliczeniu średni ELO wynosił 1603) wykazała ujemną korelację pomiędzy inteligencją a rankingiem ELO. Bilalići współpracownicy [2007], wyjaśniając uzyskane rezultaty zaproponowali dwie przyczyny leżące u ich podłoża, tj. brak stabilności w czasie rankingu ELO (wyniki testów biegłości szachowej odnoszone były do badanych dzieci, podczas gdy grupą referencyjną dla elitarnych graczy były osoby notowane w brytyjskim rankingu szachowych; uczniowie notowani w rankingu ELO różnią się liczbą sukcesów/ porażek oraz liczbą rozgrywanych turniejów szachowych). Drugą tezą jest przypuszczenie, że dzieci z grupy elitarnej o zarazem wyższym ilorazie inteligencji potrzebują mniej czasu niż gracze mniej inteligentni do osiągnięcia tych samych rezultatów $(r=0,44 ; p=0,036)$. Dane te są zbieżne $\mathrm{z}$ analizą ścieżek przeprowadzoną przez de Bruin, Kok i współpracowników [2014], która wykazała, że u 22 dzieci dopiero rozpoczynających przygodę z szachami większą rolę $\mathrm{w}$ szybszym nabywaniu wiedzy odgrywać może inteligencja $(r=0,532 ; p=0,001)$ niż kumulatywna długość trwania treningów ( $r=0,318 ; p=0,43)$, która znów skorelowana jest z satysfakcją towarzyszącą ćwiczeniom $(r=0,54 ; p=0,001)$. Jednakże

\footnotetext{
2 Zadanie polega na odwiedzeniu skoczkiem wszystkich pól planszy tak, żeby na każdym z nich stanąc tylko raz.

3 Słownik, Klocki, Kodowanie, Powtarzanie Cyfr.
} 
niezależnie od przyczyn uzyskanych przez Bilalić i wsp. [2007] rezultatów, autorzy wykazali, że zarówno cała grupa, jak i wyłonione z niej podgrupy mniej biegłych oraz elitarnych graczy odznaczają się wyższym od średniej ilorazem inteligencji (tj.: 121,6; 114 oraz 133 odpowiednio).

O ile w przypadku dzieci i młodzieży zaobserwować można związek pomiędzy inteligencją a umiejętnościami szachowymi, tak ta relacja nie jest poznana u osób dorosłych, a niewielka liczba badań i odmienne wyniki nie pozwalają na postawienie jednoznacznych wniosków, np.: grupa ośmiu mistrzów szachowych nie różniła się znacząco od grupy porównawczej poziomem inteligencji, zdolnością koncentracji oraz pamięcią wzrokowo-przestrzenną [Djakow, Petrowski i Rudik, 1927 za: Grabner, Stern, Neubauer 2007]. Dane te są zbieżne z rezultatami badań Waters, Gobet i Leyden [2002], w których grupa 12 mistrzów uzyskała podobny wynik w testach pamięci przestrzennej, jak 24 osoby mniej biegłe w szachach, a uśredniony poziom tej zdolności wszystkich badanych osób nie różnił się znacząco od 550 rekrutów marynarki wojennej USA. Z drugiej strony Dall i Mayr, dokonując pomiaru na 27 graczach, których ranking ELO wynosi 2200-2425, ustalili, że osoby te uzyskały wyższy wynik surowy w teście Cattella (Cattell's Culture Fair Intelligence Test, CFT-3) oraz wyższy iloraz inteligencji w teście BIS ${ }^{4}$ (Berlin Intelligence Structure Model), przy czym obie zmienne nie korelowały istotnie z rankingiem ELO [1987 za: Grabner i in. 2007]. Powyżej przytoczone badania sugerują więc brak związku pomiędzy eksperckim poziomem i a inteligencją.

Wartymi zwrócenia uwagi są wyniki badań przeprowadzone przez Grabner i współpracowników [2007], w których uczestniczyło 90 graczy, których ranking szachowy mieścił się w zakresie od 1311 do 2387 . Osoby te wypełniły niemiecki test inteligencji (Intelligenz-Structur-Test 2000 R, I-C-T 2000R), w ramach którego dokonywane są pomiary wyniku ogólnego, będącego składową inteligencji werbalnej, analitycznej (numerical) i przestrzennej (figural). Analiza wykazała, że szachiści jako całość, odznaczają się wyższym ilorazem inteligencji $(113,53, p<0,01)$, ale zarazem grupa nie jest jednorodna, gdyż znajdują się w niej osoby znacząco poniżej $(78,87)$, jak i powyżej $(144,38)$ średniej referencyjnej. Zdolność uzyskania tak wysokich wyników w rankingu ELO, przy jednocześnie niskim poziomie IQ może być inspiracją do pracy tą metodą również z dziećmi na granicy niepełnosprawności intelektualnej. Autorzy wykazali również umiarkowaną korelację pomiędzy inteligencją ogólną $(r=0,35 ; p<0,01)$, werbalną $(r=0,38 ; p<0,01)$ i analityczną $(r=0,46, p<0,01)$ oraz podskalnymi ją tworzącymi a rankingiem ELO. Zależności takiej nie znaleziono dla inteligencji przestrzennej. Grabner [2014] po-

\footnotetext{
4 Berlin Intelligence Structure Modell mierzy siedem wiązek zgrupowanych w dwie szersze struktury związane z treścią (content related abbilities: verbal, [M = 116.40] numerical, figural) oraz operacjami umysłowymi (operational abbilities $[\mathrm{M}=115.30]$ processing speed, memory, creativity, $[\mathrm{M}=$ 114.20] information processing capicy); Wyniki podskal, dla których osoby badane uzyskały znacząco wyższe rezultaty podano w kwadratowych nawiasach
} 
stanowił ponownie przeanalizować zgromadzone dane, tym razem jednak zwracając uwagę na inteligencję płynną i skrystalizowaną. Uzyskano podobne rezultaty (zob. tab. 1.) jak we wcześniejszych analizach, jednakże wykazano zarazem, że o ile inteligencja przestrzenna płynna nie przyczynia się do wyjaśniania wyników ELO $(r=0,02)$ o tyle skrystalizowana wnosi już istotny wkład $(r=0,30)$.

Tabela 1. Współczynniki korelacji pomiędzy komponentami inteligencji a rankingiem ELO

\begin{tabular}{|l|l|c|}
\hline \multirow{2}{*}{ Inteligencja } & płynna & skrystalizowana \\
\cline { 2 - 3 } & \multicolumn{2}{|c|}{$r$} \\
\hline Ogólna & $0,35^{* *}$ & $0,41^{* *}$ \\
\hline Werbalna & $0,38^{* *}$ & $0,24^{*}$ \\
\hline Matematyczna & $0,46^{* *}$ & $0,45^{* *}$ \\
\hline Przestrzenna & 0,02 & $0,30^{* *}$ \\
\hline
\end{tabular}

${ }^{*} \mathrm{p}<0,01 ;{ }^{* *} \mathrm{p}<0,001$

Źródło: Opracowanie własne.

Rezultaty referowanych badań pozwalają sądzić, że inteligencja na początkowym etapie przygody z szachami odgrywa większą rolę niż czas przeznaczony na samodzielne treningi [de Bruin i in. 2014], częściej również wśród wyżej notowanych graczy w rankingu ELO występują osoby ponadprzeciętnie inteligentne [Bilalić i in. 2007; Frydman, Lynn 1992]. Zarazem przeciętna inteligencja nie dyskredytuje całkowicie graczy, gdyż mogą oni osiągnąć równie wysokie rezultaty poprzez zwiększenie częstotliwości ćwiczeń [Bilalić i in. 2007]. Jednocześnie godną rozpatrzenia jest hipoteza Grabnera i współpracowników [2007], którzy sądzą, że poziom intelektu wyznacza możliwe do osiągnięcia progi (threeshold) biegłości w szachach. Autorzy zwracają bowiem uwagę, że o ile uzyskanie rankingu ELO powyżej 2000 możliwe jest dla osób o ilorazie inteligencji większym niż 85, o tyle żadna z osób badanych o rankingu 2200 nie charakteryzowała się niższym poziomem intelektu niż 110 .

\section{Szachy a osiągnięcia szkolne}

Jedną z pierwszych prac szacującą wpływ treningu szachowego na osiągnięcia szkolne jest badanie przeprowadzone na potrzeby pracy magisterskiej przez Christiaen [1976], który postanowił zweryfikować czy gra ta może przyczyniać się do szybszego rozwoju poznawczego opisanego przez Piageta. W tym celu chłopców (w wieku $M=10,7$ ) z dwóch belgijskich klas podzielił losowo do grupy kontrolnej 
$(n=20)$. Grupa eksperymentalna $(n=17)$ uczestniczyła po lekcjach w 42-godzinnych treningach szachowych (od stycznia 1975 do maja 1976 r.). W przeprowadzonej analizie porównawczej wykazano, że dzieci uczące się podstawowych reguł szachowych co prawda uzyskały lepsze oceny szkolne $(p<0,05)$, jednakże oceny te, jak i trening nie przekładają się na lepsze rezultaty $w$ wystandaryzowanych podtestach uzdolnień (m.in. słownictwo, relacje, liczenie) oraz w dwóch klasycznych testach Piageta (tj. stałość masy oraz objętości).

Dotychczasowe rezultaty z badań wnoszą przekonujące, choć nadal niewystarczające, dowody o pozytywnym wpływie treningu szachowego na osiągnięcia szkolne [Nicotera, Stuit 2014]. Wciąż pozostaje jednak wiele pytań m.in o transfer wiedzy: czy powszechny jest dla młodszych grup wiekowych oraz czy dotyczy on również dzieci zagrożonych niepowodzeniem szkolnym. Na pierwsze z nich postanowiła odpowiedzieć Sigirtmac [2012], dokonując stosownych pomiarów wśród setki dzieci w wieku 5-6 lat uczęszczających do przedszkoli zlokalizowanych w tureckim mieście Adana. Dzieci te podzielono na dwie równoliczne grupy; do pierwszej przypisano te spośród badanych przedszkolaków, które trenowały szachy, do drugiej zaklasyfikowano dzieci nieuczęszczające na zajęcia szachowe; obie zaś wychowywane były przez rodziny o wysokim statusie społeczno-ekonomicznym. Wykonano dodatkowo test, który wykazał zasadność przyjętego kryterium podziału. Wykazał on bowiem, że uczestnicy trenujący szachy posiadają większą wiedzę na temat tej gry (znajomość figur i ruchów jakie wykonują) w porównaniu do grupy kontrolnej. Na potrzeby badania utworzono narzędzie, tak by było ono możliwie podobne treściowo do szachów, ale jednocześnie nie faworyzowało żadnej z grup (tj. na planszy zbudowanej z 16 kwadratów, zamiast pionów umieszczano postacie z popularnych kreskówek np. Papa Smurf, Yogi Bear lub też różnokolorowe kwadraty). Poprzez modyfikację ułożenia użytych bodźców oraz stosowne pytania dokonano pomiaru rozwoju pojęć przestrzennych, a następnie porównano obie grupy. Przeprowadzony test U Manna-Whitneya wykazał na poziomie $p<0,005$, że przedszkolaki z grupy szachowej uzyskały znacząco wyższą częstość odpowiedzi poprawnych dla pozycji testowych, u których podłoża leży zdolność przestrzennego rozróżniania ułożenia obiektów, ich sąsiedztwa i bliskości (również po przekątnej) względem obserwatora lub innych użytych na planszy obiektów. Dzieci te znacząco lepiej również wypadły w zadaniach polegających na odtwarzaniu wzorów, symetrii oraz wskazaniu figur zlokalizowanych $\mathrm{w}$ narożniku, jednakże przewagę, jaką uzyskały przedszkolaki grające $\mathrm{w}$ szachy, tłumaczyć można zbieżnością w czasie okresu sensytywnego dla zdolności przestrzennych i treningu szachowego bowiem podobnej relacji nie uzyskano dla osób dorosłych [Waters i in. 2002]. 


\section{Szachy a dzieci ze SPE}

Dzieci ze specjalnymi potrzebami edukacyjnymi rzadko stanowią podmiot badań w tym aspekcie. Do tej pory funkcjonują tylko nieliczne doniesienia o takich dociekaniach. Jedno z takich rozważań dotyczy nauczania matematyki, $\mathrm{w}$ którym to konieczne jest zaznajomienie się $\mathrm{z}$ wieloma abstrakcyjnymi pojęciami, co szczególnie problematyczne może być dla uczniów z niepełnosprawnością intelektualną. Scholz i współpracownicy [2008] postanowili sprawdzić czy szachy stanowić mogą użyteczne narzędzie wspomagające edukację, przede wszystkim ze względu na fakt, że podczas wykonywania zadań szachowych możliwe staje się połączenie abstrakcyjnych cech figur (np. wartość pionów na szachownicy wyrażonej liczbowo na podstawie ich użyteczności wynikającej z przepisów) z ich cechami fizycznymi. Co więcej, uważa się, że szachy i matematyka są względem siebie izomorficzne [zob. Sala, Gorini, Praventtoni 2015].

Innymi słowy Scholz i współpracownicy [2008] postanowili sprawdzić czy szachy "obniżyć" mogą stopień abstrakcyjności koncepcji matematycznych. W tym celu spośród czterech szkół w Niemczech wyselekcjonowano siedem klas, do których uczęszczały dziesięcioletnie dzieci z obniżonym poziomem inteligencji (od 70 do 85) a następnie losowo dokonano podziału na grupę kontrolną $(n=22)$. W grupie eksperymentalnej $(n=31)$ jedną z pięciu cotygodniowych lekcji matematyki przeznaczono na zajęcia, podczas których uczono dzieci podstawowych reguł szachowych. Pod koniec roku szkolnego wykorzystując ANOVA dokonano porównania poziomu biegłości z ich bazowym poziomem oraz estymowano istotność różnic $\mathrm{w}$ ich przyroście pomiędzy wyróżnionymi grupami. Przeprowadzona analiza wykazała na poziomie $p=0,001$, że wraz z upływem czasu uczniowie nabywają większą biegłość w rachowaniu, przy czym dla rozwiązywania prostych zadań z treścią oraz uzupełniania brakujących cyfr w równaniu (np. $t+1=5$ ) trening szachowy nie przyczynia się do znaczącego wzrostu tych zdolności $(p<0,05)$. Zaobserwowano jednak, że dla zliczania, sumowania i odejmowania liczb (counting and simple calculation), roczny trening szachowy zwiększa 2,25-krotnie szansę powodzenia $(p 0,001)$.

Powodzenie szkolne zależne jest od wielu czynników, a jednym z nich, choć nie będący gwarantem sukcesu, jest inteligencja [Nęcka, Orzechowski, Szymura 2006]. Hong i Bart [2007] postanowili sprawdzić czy trening szachowy wpłynąć może na poprawę wyników niewerbalnych testów inteligencji (TMR; The Test of Nonverbal Intelligance - Third Edidtion, TONI-3). W drodze podziału losowego 38 uczniów szkół podstawowych zlokalizowanych w Seulu, osiągających niskie efekty edukacyjne w klasach od trzeciej do szóstej, utworzyło 20-osobową grupę kontrolną. Pozostała część uczestników badania $(\mathrm{n}=18)$ w trakcie 12-półtorago- 
dzinnych lekcji uczona była ogólnych reguł szachowych, tworzenia wyprzedzających strategii ruchu pionów (feedforward) i wcielania tych planów w życie oraz sprawdzania ich skuteczności. Przeprowadzony test $2 \times 2$ ANOVA z powtarzanymi pomiarami, podczas którego szacowano związek interwencji oraz upływu czasu na rezultaty testów inteligencji, wykazał, że obie grupy uzyskały znacząco lepsze wyniki w TMR $(p<0,05)$ oraz TONI-3 $(p<0,001)$, natomiast trening szachowy nie odgrywał $w$ tym przyroście znaczącej roli $(p<0,05)$. Przeprowadzając dodatkowo analizę korelacji cząstkowej (kontrolując rezultaty w pre-teście) zaobserwowano jednakże, że ranking szachowy ELO stanowić może użyteczny wskaźnik przyrostu wyników testu TONI-3 $(r=0,52 ; p<0,05 ; d=0,29)$.

$\mathrm{W}$ stanie Teksas corocznie w szkołach podstawowych przeprowadzany jest pomiar wiedzy matematycznej TAKS (Texas Assessment of Knowledge and Skills), od wyniku którego zależy promocja uczniów do następnej klasy. Barrett i Fish (2011) prześledzili procent uczniów uzyskujących minimalną wymaganą liczbę punktów (tj. 2100) w latach 2003-2009 i zaobserwowali, że z każdym rokiem zmniejsza się odsetek dzieci z wynikami pozytywnymi, a zależność ta szczególnie wyraźna jest u dzieci SPE (np. ogólny wskaźnik uzyskanych promocji w klasach trzecich wynosił $85,6 \%$, podczas gdy dla dzieci SPE był on równy 79,6\% [różnica $=6$ p.p.], natomiast $w$ klasach jedenastych proporcje te wynosily odpowiednio $79,4 \%$ oraz $44 \%$ [różnica $=35,4$ p.p.]).

Te niepokojące dane skłoniły cytowanych autorów do sprawdzenia czy trening szachowy przydatny może być w redukcji liczby uczniów z niepowodzeniami szkolnymi. W tym celu z klas 6-8 zrekrutowano 31 uczniów, ze zdiagnozowanymi deficytami (m.in. zaburzenia przetwarzania słuchowego, zaburzenia zachowania, zaburzenia emocjonalne, zaburzenia uczenia się, autyzm), które znacząco niekorzystnie przekładały się na ich możliwości szkolne. Piętnastu z nich przez 30 tygodni uczęszczało na 50-minutowe zajęcia szachowe prowadzone w ramach szkolnych lekcji. Po roku dokonano pomiarów na obu grupach, a następnie testem ANCOVA przeprowadzono analizę porównawczą uzyskanych wyników. Wykazała ona, że trening szachowy znacząco związany jest z lepszymi ocenami końcowymi z matematyki $(r=0,418 ; p 0,001)$ oraz rezultatami testu TAKS $(r=0,253 ; p<0,005) \mathrm{w}$ odniesieniu do wyników z roku poprzedniego (zaznaczyć jednak należy, że nie przeprowadzono testu równoważności grup, a jedynie uwzględniono kowariancję pre-testu). Stanowczo podkreślić należy, że grupa porównawcza uzyskała średnio 2084,75 punktów w teście TAKS, podczas gdy grupa szachowa uzyskała około 2191,67 ( $p<0,05)$, co oznacza, że otrzymaliby promocję do następnej klasy. Pogłębiona analiza wykazała jednak, że spośród sześciu celów leżących u podstaw nauczania matematyki, których stopień zrealizowania mierzy właśnie TAKS, tylko dla dwóch z nich grupa szachowa uzyskała znacząco lepszy wynik, tj. dla umiejętności operowaniem liczbami (number, operation), i rozumo- 
wania ilościowego (quantitative reasoning) $(r=0,21 ; p<0,05)$ oraz dla zdolności wykorzystania wiedzy matematycznej $\mathrm{w}$ życiu codziennym (underlying processes and mathematical tools; $r=0,129 ; p=0,056)$.

\section{Podsumowanie}

Z punktu widzenia nauki królewska gra jawi się jako potencjalne źródło dobrze usystematyzowanego materiału badawczego, który bazować może o dostęp do protokołów milionów partii, dzięki czemu możliwe jest prowadzenie post factum podłużnych i poprzecznych analiz. Właśnie na podstawie takich badań dokonano obserwacji, że cechy leżące u podstaw eksperckiej wiedzy nie są ściśle związane z wiekiem biologicznym [Schneider, Gruber, Gold, Opwis 1993]. Oznacza to, że jest to gra dla wszystkich i na każdym etapie wiekowym można osiągnąć mistrzostwo. Mistrzowie charakteryzują się sprawniejszym przeszukiwaniem zasobów pamięciowych, przez co podejmują szybciej trafniejsze decyzje. Niestety, badania pokazują, że do osiągnięcia poziomu eksperckiego w szachach konieczne jest w przybliżeniu około 10 tys. godzin treningu, czyli około 10 lat. $\mathrm{W}$ odniesieniu do edukacji, która w naszym systemie jest podzielona na 3-letnie odcinki, jest czasem zdecydowanie zbyt długim. Jednakże na podstawie badań i metaanalizy [zob. Nicotera, Stuit 2014; Sala, Gorini, Pravettoni 2015; Trinchero 2013] można zaobserwować, że w początkowym okresie nauki gry, zdolności, które są konieczne do nabywania biegłości i wiedzy szachowej, są spójne również ze zdolnościami potrzebnymi $\mathrm{w}$ innych dziedzinach życia (umiejętności matematyczne, kompetencje społeczne, pamięć). Stąd też ustalić należy długość treningu, który jest potrzebny nie do zdobycia mistrzostwa (które jest długotrwałe a przy tym nie gwarantuje transferu wiedzy), ale do odkrycia najefektywniejszego czasu, podczas którego poza rozrywką i nauką towarzyszącą grze w szachy, towarzyszyć będzie poprawa kompetencji i umiejętności przydatnych w szkole i w życiu.

Pierwsze wyniki bazujące na tej perspektywie pozwalają stwierdzić, że roczny trening szachowy zwiększa 2,25-krotnie szansę powodzenia $(p<0,001$; Scholz i in. 2008) w zliczaniu, sumowaniu i odejmowaniu liczb u dzieci ze SPE, a także, że wprowadzenie jednej godziny szachów zamiast jednej lekcji matematyki nie zmienia wyników w ogólnych testach z matematyki - co wskazuje na podobny rozwój dzieci w tym obszarze. Bardzo ważną kwestią wydaje się też być zbadanie kompetencji społecznych u dzieci biorących udział w programie, gdyż wielokrotne stawanie $w$ sytuacji wygranego, ale również przegranego, może mieć znaczące znaczenie dla tego aspektu. Wydaje się również ważną kwestią, że 
dzieci ze SPE, które mogą nie mieć zbyt wielu pozytywnych doświadczeń ze szkołą jako instytucją, w grze w szachy uczą się przegrywać i wygrywać, a także radzić sobie z emocjami towarzyszącymi tym wydarzeniom, co może mieć niebagatelny związek ze wzrostem poczucia własnej wartości i samooceny.

\section{Bibliografia}

Barrett D. C., Fish W. W. (2011), Our Move: Using Chess to Improve Math Achievement for Students Who Receive Special Education Services, „International Journal of Special Education”, 26(3), s. 181-193.

Bilalić M., McLeod P., Gobet F. (2007), Does chess need intelligence? - a study with young chess players, "Intelligence”, 35(5), s. 457-470.

Campitelli G., Gobet F. (2008), The role of practice in chess: A longitudinal study, „Learning and individual differences", 18(4), s. 446-458.

Campitelli G., Gobet F. (2011), Deliberate practice necessary but not sufficient, „Current Directions in Psychological Science", 20(5), s. 280-285.

Campitelli G., Parker A., Head K., Gobet F. (2008), Left lateralization in autobiographical memory: An fmri study using the expert archival paradigm, "International Journal of Neuroscience", 118(2), s. 191-209.

Charness N. (1992), The impact of chess research on cognitive science, „Psychological Research”, 54, s. 4-9.

Christiaen J. (1976), Schaken en Cognitieve Ontwikkeling, Rijksuniversiteit Gent, Gent, Belgium (nieopublikowana praca magisterska).

de Bruin A.B., Kok E.M., Leppink J., Camp G. (2014), Practice, intelligence, and enjoyment in novice chess players: A prospective study at the earliest stage of a chess career, "Intelligence”, 45, s. $18-25$.

de Bruin A. B., Rikers R., Schmidt H. G. (2007), The influence of achievement motivation and chess-specific motivation on deliberate practice, "Journal of Sport and Exercise Psychology", 29(5), s. 561-583.

de Bruin A.B., Smits N., Rikers R.M., Schmidt H.G. (2008), Deliberate practice predicts performance over time in adolescent chess players and drop-outs: A linear mixed models analysis, „British Journal of Psychology”, 99(4), s. 473-497.

Ericsson K.A., Charness N. (1994), Expert performance: Its structure and acquisition, „American psychologist", 49(8), s. 725- 747.

Ericsson K.A., Charness N., Feltovich P.J., Hoffman R.R. (red.) (2006), The cambridge handbook of expertise and expert performance, Cambridge University Press.

Ericsson K.A., Krampe R.T., Tesch-Römer C. (1993), The role of deliberate practice in the acquisition of expert performance, „Psychological review”, 100(3), s. 363-406.

Frydman M., Lynn R. (1992), The general intelligence and spatial abilities of gifted young belgian chess players, "British journal of Psychology”, 83(2), s. 233-235.

Glickman M.E. (1995), Chess rating systems, „American Chess Journal”, 3(59), s. 102.

Glickman M.E., Jones A.C. (1999), Rating the chess rating system, "Chance-Berlin Then New York", 12, s. 21-28.

Gobet F. (2013), Expertise vs. talent, „Talent Development \& Excellence”, 5, s. 75-86. 
Gobet F., Campitelli G. (2007), The role of domain-specific practice, handedness, and starting age in chess, "Developmental psychology”, 43(1), s. 159-172.

Gobet F., Charness N. (2006), Expertise in Chess [w:] Ericsson K.A., Charness N., Feltovich P.J., Hoffman R.R., The Cambridge handbook of expertise and expert performance MA: Cambridge University Press, s. 683-703.

Grabner R.H., (2014), The role of intelligence for performance in the prototypical expertise domain of chess, "Intelligence”, 45, s. 26-33.

Grabner R.H., Stern E., Neubauer A.C. (2007), Individual differences in chess expertise: A psychometric investigation, „Acta psychological”, 124(3), s. 398-420.

Hambrick D.Z., Oswald F.L., Altmann E.M., Meinz E.J., Gobet F., Campitelli G. (2014), Deliberate practice: Is that all it takes to become an expert?, „Intelligence”, 45, s. 34-45.

Hambrick D.Z., Macnamara B.N., Campitelli G., Ullén F., Mosing M.A. (2016), Chapter OneBeyond Born versus Made: A New Look at Expertise, „Psychology of Learning and Motivation", 64, s. 1-55.

Hong S., Bart W.M. (2007), Cognitive effects of chess instruction on students at risk for academic failure, "International Journal of Special Education”, 22(3), s. 89-96.

Horgan D.D., Morgan D. (1990), Chess expertise in children, "Applied Cognitive Psychology", $4(2)$, s. 109-128.

Howard R. W. (2009), Individual differences in expertise development over decades in a complex intellectual domain, "Memory \& Cognition”, 37, s. 194-209.

Howard R. W. (2012), Longitudinal effects of different types of practice on the development of chess expertise, „Applied Cognitive Psychology”, 26(3), s. 359-369.

Macnamara B. N., Hambrick D. Z., Oswald F. L. (2014), Deliberate practice and performance in music, games, sports, education, and professions a meta-analysis, „Psychological science”, 25(8), s. $1608-1618$.

Nicotera A., Stuit D. (2014), Literature Review of Chess Studies. s. 1-35, http://londonchessconference.com/wp-content/uploads/2014/11/CCSCSL-Literature-Review-of-ChessStudies-November-20141.pdf [dostęp: 20.05.2016].

Nęcka E., Orzechowski J., Szymura B. (red.) (2006), Psychologia poznawcza, Wydawnictwo Szkoły Wyższej Psychologii Społecznej Academica, Warszawa.

PE (2012), Oświadczenie parlamentu europejskiego z dnia 15 marca 2012 r. w sprawie wprowadzenia do systemów oświaty w unii europejskiej programu "Szachy w szkole" (Tech. Rep.), http://www.europarl.europa.eu/sides/getDoc.do?pubRef=-//EP//TEXT+ TA+P7-TA-2012-0097+0+DOC+XML+V0//PL [dostęp: 20.05.2016].

PZSzach (2014), Sprawozdanie zarządu Polskiego Związku Szachowego za okres 2013 roku oraz do 14 czerwca 2014 roku (Raport techniczny), http://www.pzszach.org.pl/pub/ 1/173/Sprawozdanie Zarzadu Polskiego Zwiazku Szachowego za okres za okres 2013 roku oraz do 14 czerwca 2014 roku.doc. [dostęp: 20.05.2016.

Sala G., Gorini A., Pravettoni G. (2015), Mathematical problem-solving abilities and chess, „,SAGE Open", 5(3), s. 1-9.

Schneider W., Gruber H., Gold A., Opwis K. (1993), Chess expertise and memory for chess positions in children and adults, ,Journal of Experimental Child Psychology, 56(3), s. 328-349.

Scholz M., Niesch H., Steffen O., Ernst B., Loeffler M., Witruk E., Schwarz H. (2008), Impact of Chess Training on Mathematics Performance and Concentration Ability of Children with Learning Disabilities, „International Journal of Special Education”, 23(3), s. 138-148. 
Sigirtmac A. D. (2012), Does chess training affect conceptual development of six-year-old children in turkey?, „Early Child Development and Care”, 182(6), s. 797-806.

Simon H. A., Chase W. G. (1973), Skill in chess, "American Scientist”, 61(4), s. 394-403.

Sternberg R. J. (1996), Costs of expertise [w:] The road to excellence: The acquisition of expert performance in the arts and sciences, sports, and games, red. K.A. Ericsson, Psychology Press. New York-London, s. 347-354.

Trinchero R. (2013), Can chess training improve Pisa scores in mathematics. An Experiment in Italian Primary School, Paris: Kasparov Chess Foundation Europe, s. 1-17, https://saintlouischessclub.org/sites/default/files/TRINCHERO_ND_CHESS.pdf [dostęp: 20.05.2016].

Waters A.J., Gobet F., Leyden G. (2002), Visuospatial abilities of chess players, „British Journal of Psychology", 93(4), s. 557-565

W Polityce (2016, 12 październik). Zaskakujący pomyst Anny Zalewskiej, http://wpolityce.pl/ polityka/308114-zaskakujacy-pomysl-anny-zalewskiej-juz-do-pierwszych-klas-szkolypodstawowej-wprowadzimy-gre-w-szachy [dostęp: 20.05.2016].

TVP Info, (2016, 12 październik). 24 minuty. Wywiad przeprowadzony z MEN Anną Zalewską przez Krzysztofa Skowrońskiego. 